\title{
ОСОБЛИВОСТІ ПІДГОТОВКИ ВОКАЛІСТІВ У МУЗИЧНИХ ЗАКЛАДАХ ВИЩОЇ ОСВІТИ КНР
}

\section{Чжан Вей}

здобувач третього (освітньо-наукового) рівня вищої освіти кафедри освітології та інноваційної педагогіки, Харківський національний педагогічний університет імені Г. С. Сковороди, Україна - Китай

Підготовка вокалістів у музичних закладах КНР має багато націіональних особливостей, проте все більше у ичі процеси втручається глобалізація та відкритість китайського суспільства до світу. До основних особливостей можна віднести: розгалужену методологію підготовки, акцент на патріотизм та ідеологію у навчанні.

Ключові слова: вокалісти, методи, заклади вищуої освіти, КНР.

The training of vocalists in Chinese music institutions has many national characteristics, but globalization and the openness of Chinese society to the world are increasingly interfering in these processes. The main features include: extensive training methodology, emphasis on patriotism and ideology in education.

Key words: vocalists, methods, institutions of higher education, China.

У XXI столітті Китайська Народна Республіка проголошує нове «суспільство знань» в глобальну епоху. Такий поворот у суспільних відносинах китайського суспільства дозволив приділити більше уваги та ресурсів розбудові якісної освіти. 3’являється «освіта цінностей» яка пов'язана 3 викладанням як музичних, так і немузичних значень у подвійному контексті націоналізму та глобалізації. Процеси глобалізації змусили освіту вирішувати очевидне протиріччя між національною ідентичністю та національною єдністю у постійно мінливій «грі» китайської історії та політики. Музична освіта за новим підходом може поєднувати, на перший погляд, суперечливі речі які є у навчальних програмах зокрема: між сучасними культурними та соціальними цінностями, з одного боку, і традиційними китайськими та комуністичною ідеологією, з іншого; між колективізмом та індивідуалізмом; і між національною та глобальною культурами [3].

У Китаї існують три типи вищих навчальних закладів, які готують спеціалістів 3 вокального мистецтва: консерваторії, педагогічні вищі навчальні заклади та непедагогічні вищі навчальні заклади. У свою чергу, китайські консерваторії мають свої стандарти з цієї спеціаль- 
ності, які дещо відрізняються від вимог китайського університету. Проте слід зазначити, що в консерваторіях та університетах китайські студенти - майбутні вокалісти навчаються 4 роки, після чого випускники отримують диплом бакалавра. Більше того, в Китаї ступінь бакалавра вважається повною вищою освітою.

У КНР всі навчальні програми поділяють дисципліни на три категорії: загальногуманітарні, загальнопрофесійні та спеціальні дисципліни. У КНР, студенти повинні не тільки здобути необхідний мінімум гуманітарних знань, а й виховувати світогляд. У ЗВО Китаю відсутні такі дисципліни, як філософія, історія світової культури і музики, етномузикологія тощо. Особливістю підготовки вокалістів у КНР є їх педагогічна спрямованість, тобто більшість випускників закладів вищої музичної освіти стають вчителями у загальноосвітніх та музичних школах. В Китаї підготовка вчителів середньої освіти (у тому числі музичної) здійснюється лише в консерваторіях і мистецьких закладах вищої освіти. Натомість є вищі навчальні заклади, які підтримують традиційну модель підготовки вокалістів, яка фактично ігнорує специфіку педагогічних кафедр і факультетів.

У контексті даного дослідження вважаємо за доцільне виділити використання методів підготовки вокалістів у процесі навчання. Отже, говорячи про методику підготовки вокалістів у системі вищої музичної освіти, слід звернути увагу не тільки на методи, які дозволяють вокалістам виявити індивідуальні особливості у виконанні вокальних творів, а й на ті методи, які однаково ефективні у навчанні всіх вокалістів та враховують закономірності процесу підготовки фахівців вокального мистецтва [4].

Нині в Китаї у вокальному навчанні часто використовуються такі загальні музичні методики [2]:

1) «Методика експерименту», коли через досвід чуттєвого сприйняття пробуджується інтерес до вивчення вокалу. Він включає 2 засоби: насолоду від музики, для чого вчитель на уроці створює середовище, в якому учні відчувають об'єктивність речей за допомогою конкретних педагогічних матеріалів. Наприклад, вивчаючи неаполітанську пісню «Santa Lucia», вчитель покаже відео про море, місяць. Друге - демонстрація. Тобто вчитель може проілюструвати, як співати, іноді за допомогою аудіо- та відеозасобів, щоб показати учням, як співає інший професійний 
співак. Цей інструмент вважається найефективнішим у навчанні вокалу.

2) «Практична методика». Вважається, що найважливішим у навчанні є музична практична діяльність. Учитель веде учнів, самі учні беруть участь у різноманітних музичних практиках та набувають виконавського досвіду. Тут важливо правильно підібрати вправи, за допомогою яких учні намагаються застосувати накопичені теоретичні знання на практиці, втілюючи задум у виконанні того чи іншого вокального твору.

3) «Мовна методика» включає лекційні, розмовні та дискусійні методи. Ця методологія більше підходить для демонстрації відкритих уроків і семінарів, де більше уваги приділяється теоретичним аспектам.

4) «Методологія дослідження». Учитель організовує навчальнодослідницьку діяльність учнів, спрямовану на спостереження, аналіз і порівняння музичних матеріалів. Цей метод є одним із найефективніших, адже найважливіше, чого може навчити вчитель, - це вміння вчитися самостійно. У цьому випадку навчальний процес після закінчення навчання не закінчується, а стає способом життя, а вокаліст постійно вдосконалює свою професійну майстерність [2].

Використання цифрових технологій при навчанні китайських студентів вокалу у ЗВО, дає підстави для підвищення вокального розвитку на всіх рівнях навчання від дитячих дошкільних навчальних закладів до вищої освіти, що може бути реалізовано $з$ використанням сучасних цифрових технологій. Для розвитку музичної культури через вивчення вокальних творів та виконавців різних національностей студентам можна запропоновано теоретичне вивчення історії різних напрямів, жанрів і стилів, а також практичне навчання через виконання вокальних творів у цифровом просторі. Для формування вокальних навичок та естрадних прийомів студентам пропоновано комплекс вправ і завдань, розроблених на основі сучасних вокальних методик з залученням цифрових засобів навчання та виконання [1].

\section{Список використаних джерел:}

1. Konovalova S. A., Zhang T., \& Sun D. Digital Technologies in Vocal Training of Chinese Students in Russian Higher Education Institutions. In International 
Scientific Conference "Digitalization of Education: History, Trends and Prospects"(DETP 2020), (2020, May). (pp. 32-36). Atlantis Press.

2. Li Zhen. Vocal technique based on music. Chinese economy. Series «Pedagogy». 2008. № 4. pp. 184-185. (in Chinese).

3. Wai Chung Ho \& Wing Wah Law Values, music and education in China, Music Education Research. 2004.6(2). pp. 149-167, DOI: $10.1080 / 1461380042000222564$

4. Zhang Lianhong Content Features of Vocalists' Professional Training in the System of Higher Music Education of China And Ukraine: a Comparative Analysis. The Scientific Heritage. 2021.59 (3). pp. 40-43. DOI: 10.24412/92150365-2021-59-3-40-43 